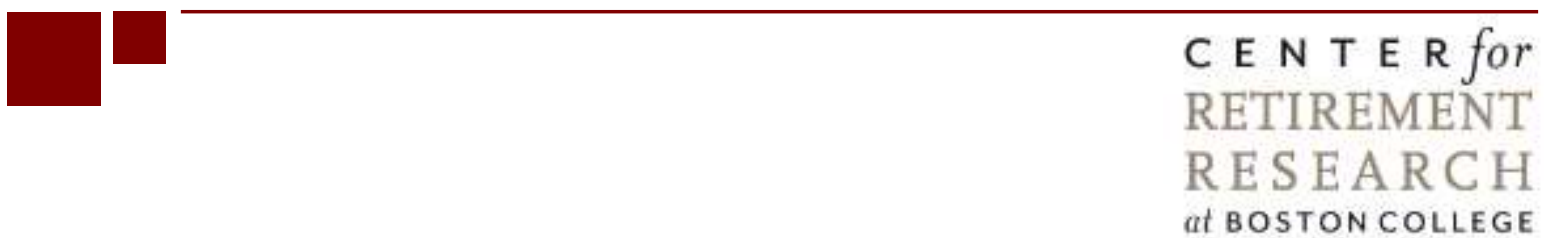

\title{
SOCIAL SECURITY AND THE 2001 REFORM OF THE RAILROAD RETIREMENT PROGRAM
}

\author{
Steven A. Sass \\ CRR WP 2013-15 \\ Released: June 2013 \\ Center for Retirement Research at Boston College \\ Hovey House \\ 140 Commonwealth Avenue \\ Chestnut Hill, MA 02467 \\ Tel: 617-552-1762 Fax: 617-552-0191 \\ http://crr.bc.edu
}

Steven A. Sass is the program director of the Financial Security Project at Boston College, an initiative of the Center for Retirement Research. The research reported herein was pursuant to a grant from the Burlington Northern Santa Fe Railway Company, CSX Corporation Inc., Norfolk Southern Corporation, and Union Pacific Corporation. The findings and conclusions expressed are solely those of the author and do not represent the views of the Burlington Northern Santa Fe Railway Company, CSX Corporation Inc., Norfolk Southern Corporation, Union Pacific Corporation, or Boston College.

(C) 2013, Steven A. Sass. All rights reserved. Short sections of text, not to exceed two paragraphs, may be quoted without explicit permission provided that full credit, including $(\subset$ notice, is given to the source. 


\begin{abstract}
About the Center for Retirement Research
The Center for Retirement Research at Boston College, part of a consortium that includes parallel centers at the University of Michigan and the National Bureau of Economic Research, was established in 1998 through a grant from the Social Security Administration. The Center's mission is to produce first-class research and forge a strong link between the academic community and decision-makers in the public and private sectors around an issue of critical importance to the nation's future. To achieve this mission, the Center sponsors a wide variety of research projects, transmits new findings to a broad audience, trains new scholars, and broadens access to valuable data sources.
\end{abstract}

\author{
Center for Retirement Research at Boston College \\ Hovey House \\ 140 Commonwealth Avenue \\ Chestnut Hill, MA 02467 \\ phone: 617-552-1762 fax: 617-552-0191 \\ e-mail: crr@bc.edu \\ crr.bc.edu
}

Affiliated Institutions:

The Brookings Institution

Massachusetts Institute of Technology

Syracuse University

The Urban Institute 
The histories of the federal Railroad Retirement program and Social Security have long been closely connected. Railroad Retirement was created one year before Social Security, when the government took over the tottering pension plans of the nation's railroad industry. The new federal program had the same pay-as-you-go social insurance structure that Congress would use for Social Security. Both programs would add ancillary social welfare benefits, for spouses and other dependents. The finances of both were significantly shored up in 1983, by the same Congressional committees, responding to similar financial issues. And the use of equities became central to proposals to reform each program in the 1990s.

From the creation of the Railroad Retirement and Social Security programs in the 1930s through the end of the 1990s, the Trust Funds of each program held only U.S. Treasury bonds. A well-established principle of finance nevertheless held that equities offered higher expected returns than Treasuries, at the price of higher expected risk. The long bull market in stocks, running from the early 1980s through the end of the 1990s, provided a powerful object lesson on higher returns on equities; and barely any lesson at all on higher risk. As described in the first discussion essay, the appeal of higher returns on Railroad Retirement assets, if those assets were invested in equities, was the driving force behind the 2001 reform. When the 1994-96 Social Security Advisory Council addressed in earnest Social Security's long-term financing shortfall, all three proposals the Council members presented included the use of equities. ${ }^{1}$ While none of these Social Security proposals has been enacted in the United States, other nations, such as Canada, Ireland, Japan, New Zealand, and Sweden, adopted a policy of investing social security trust fund assets in equities in the years between 1995 and 2001. ${ }^{2}$

The 2001 Railroad Retirement reform introduced equities, and the higher expected returns they offered, to cut taxes and raise benefits. The Advisory Council proposals embraced equities as an alternative to closing Social Security's financing shortfall the "old fashioned" way - by raising taxes or cutting benefits. There was real resistance to raising Social Security payroll taxes. The payroll tax had become by far the largest tax most workers paid, at 15.3 percent of covered earnings (10.2 percent for Old Age and Survivors' Insurance; 1.8 percent for Disability Insurance; and 2.9 percent for Medicare. While the payroll tax is formally "split evenly" between employers and workers, the employer portion is part of labor compensation and

\footnotetext{
${ }^{1}$ U.S. Social Security Administration (1997).

${ }^{2}$ Palacios (2002).
} 
generally viewed by economists as reducing employee earnings nearly dollar for dollar, and thus largely borne by workers.)

There was also real resistance to cutting benefits. Social Security was already scheduled to replace a significantly smaller share of household pre-retirement earnings for retirement at any given age, due to the increase in the Full Retirement Age from 65 to 67 between 2000 and 2017. Combined with projected increases in the taxation of benefits and in Medicare Part B premiums, which are deducted from Social Security checks, benefits are expected to replace less than 30 percent of the "average worker's" pre-retirement earnings by 2030, significantly less than the 40 percent of the mid-1990s. ${ }^{3}$

The three Advisory Council proposals, which remain the primary options for introducing equities into the Social Security program, were to

- Invest a portion of the Social Security Trust Fund assets in equities.

- Continue to invest Social Security Trust Fund assets in Treasuries and reduce benefits to what the program could finance; but add mandatory contributions to an individual retirement savings account that could be invested in equities.

- Allow workers to divert a portion of their Social Security payroll tax to an individual account, which could be invested in equities, in exchange for a reduction in future Social Security benefits.

The Democrats under President Clinton had proposed adopting the first option - to invest a portion of the Social Security Trust Fund assets in stocks. ${ }^{4}$ The Republicans under President Bush had proposed the third option -allowing workers to carve out a portion of their Social Security payroll tax to fund individual accounts where the funds could be invested in stocks. ${ }^{5}$ And each side vehemently opposed the other's proposal. The Democrats viewed carve-out accounts as gutting, and potentially killing, the social insurance safety-net created by Franklin Roosevelt. The Republicans viewed the government investing the Social Security Trust Fund in equities as crossing a critical red line in its involvement in the private economy. President Bush, in particular, made Social Security reform a major policy initiative. And he did so just as the railroad industry brought their proposal to Congress.

\footnotetext{
${ }^{3}$ Munnell and Sass (2006), p.12. The increased employment of married women, which raised a household's preretirement earnings far more than post-retirement benefits, further diminished Social Security's role in providing an income to the nation's elderly. Munnell, Sanzenbacher, and Soto (2007).

${ }^{4}$ Clinton (1999).

${ }^{5}$ See, for example, Greenspan (2001).
} 
The industry proposed that the Railroad Retirement Trust Fund invest in equities and other private securities - like a pension trust in a private employer defined benefit plan. The rub, however, was that Railroad Retirement was a government program and its assets were government assets. Investing the program's Trust Fund in equities was widely seen as creating a precedent for doing the same with Social Security. This was an unwanted complication for the industry as it generated stiff opposition that nearly scuttled the proposed reform - especially from Republican proponents of President Bush's individual account alternative.

Some Republican lawmakers suggested that the industry consider converting Railroad Retirement into a 401(k)-type individual account program. But that was a total non-starter. The unions would never accept the transition. Nor was management interested. If equities were to be introduced into the Railroad Retirement program, it would have to be done using the assets in the Railroad Retirement Trust Fund.

Congress in the end enacted a reform of the Railroad Retirement program that included the investment of Trust Fund assets in equities. As discussed in the second discussion essay, Congress did what it could to distance the investment process as much as possible from government. The experience of the reformed Railroad Retirement program nevertheless has implications for the investment of Social Security Trust Fund assets in equities. The most important implications, in increasing order of importance, are in i) budgetary accounting, ii) the governance of Trust Fund investment, and iii) dealing with risk.

\section{IMPLICATIONS FOR SOCIAL SECURITY: BUDGETARY ACCOUNTING}

Accounting shouldn't influence policy. But it does. Railroad Retirement assets are government funds. And the accounting treatment of Railroad Retirement investments in equities and other private securities was, in the words of the Congressional Budget Office, "a significant departure from traditional federal transactions." 6 This treatment, and its influence on policy decisions, would likely be extended to the investment of the Social Security Trust Fund assets in private securities.

When the industry went to Congress, the initial judgment of the government's budgetary authorities - the Congressional Budget Office and the Office of Management and Budget - was

\footnotetext{
${ }^{6}$ Congressional Budget Office (2003) pp. 12.
} 
that the purchase of private securities by the new National Railroad Investment Trust (NRRIT) should be scored as current government expenditure. Initial CBO estimates projected the size of the expenditure - and thereby the increase the size of the federal deficit - at $\$ 15.3$ billion. ${ }^{7}$ And this almost killed the reform.

Selling Treasuries and buying private securities would not be considered expenditure in "normal" accounting. The transaction would affect neither the income statement nor the balance sheet. But government accounting isn't "normal."

Government accounting is "cash" not "accrual" accounting. It does not distinguish between the purchase of "consumption" items that will be used within a year, such as copy paper or a welfare payment, and the purchase of "investment" items, such as a battleship with a 50 year life expectancy. Expenditures on copy paper and expenditures on battleships are both recorded as current expense. Normal "accrual" accounting, by contrast, would depreciate the cost of the battleship over its 50-year life expectancy and consider only a portion (say $1 / 50^{\text {th }}$ ) as a current expense. This is considered good practice as it records expense in time when good or service provides an economic contribution. But for a variety of reasons, among them the difficulty of determining the useful life of many government purchases, government accountants have adopted the simple cash accounting framework.

Consistent with cash accounting, OMB Circular A-11 instructs government accountants to "treat an investment in non-U.S. securities (equity or debt securities) as a purchase of an asset. You must record an obligation and an outlay for the purchase in an amount equal to the purchase price." According to this procedure, the NRRIT's purchase of private securities would be booked as current government expenditure.

Nor would government accounting offset this "outlay" with the NRRIT's sale of Treasuries of equivalent value. OMB Circular A-11 instructs government agencies to treat Treasuries as equivalent to cash, and the purchase or sale of Treasuries "as a change in the mix of asset holdings rather than as a purchase or sale of assets." Buying private securities is expenditure. Selling Treasuries is a non-event. Assuming the NRRIT would retain about 20 percent of its assets in Treasuries and use the proceeds from the sale of the remainder to purchase private securities, the CBO came up with its $\$ 15.3$ billion expenditure figure.

\footnotetext{
${ }^{7}$ Congressional Budget Office (2001) pp. 1, 5.
} 
Whatever the rationale for cash-basis accounting for general government operations, it made little sense for a pension plan. Government accounting prior to 1969 had in fact separated the accounts of Social Security from the rest of the budget. The finances of Social Security are still addressed independently of the accounts of general government operations in the annual Social Security Trustees Report. Since 1969, however, government accounting included Social Security in the federal "unified budget" and reported its operations, as part of the government's "unified" operations, on a cash accounting basis. For decades government accounting thus reported Social Security running "surpluses" - while the actuarial projections in the Trustees' Reports showed the program in increasingly deep financial trouble.

The railroad team negotiating with Congress recognized the political impediment this accounting treatment created. As it turned out, cash accounting was not universally applied in government accounting. In the Credit Reform Act of 1990, Congress specified by statute that direct student and home loans be treated as "a means of financing" - so extending such loans would not be recognized as a current budgetary outlay. The railroad team succeeded in getting similar treatment for Railroad Retirement investments in private securities. To prevent the sale of Treasuries and purchase of private securities from creating a budgetary deficit - an accounting illusion that disguised what in effect was an exchange of assets of equal value - the 2001 legislation specified that purchases of private securities by the NRRIT be scored as a neutral "means of financing."

With the treatment of securities purchases settled by statute, the CBO and OMB specified the reporting of annual income. The budgetary offices required interest, dividends, rents, and realized and unrealized capital gains be recorded as government revenue - or a government outlay should capital losses exceed interest, dividend, and rental income.

Should Congress chose to invest Social Security assets in equities, the "means of financing" precedent established by the NRRIT could be used to avoid recording an enormous an illusory - expenditure and deficit when exchanging Treasuries for private-sector securities. A conservative critic of the 2001 reform noted that this budgetary treatment created a bias in favor of using the Trust Fund, not carve-out individual accounts, for introducing equities into the Social Security program. Payroll taxed diverted to carve-out individual accounts would clearly reduce government revenues, with the reduction duly recorded on the government's books. As 
government accounting is cash accounting, the reduction in future Social Security benefit obligations, resulting from the diversion of payroll taxes, would not be recorded.

While the "means of financing" treatment would avoid a major political impediment to investing the Social Security Trust Fund in equities, the treatment of the NRRIT's annual income and loss does not. With a Social Security Trust Fund now holding over \$2 trillion, the volatility of equity prices can be expected to regularly generate capital gains and losses in the $\$ 100$ s of billions. In a unified budget context, these gains and losses flow directly to the budgetary "bottom line." They would also tend to be strongly pro-cyclic: large capital losses in downturns, reported as "outlays," would widen budget deficits; large capital gains in upturns, reported as revenues, would shrink or eliminate budgetary deficits. Swings in the value of equities held in individual accounts - whether "carve out" or "add on" accounts - would trouble or please the account holder. But they have no direct effect on the federal budget. If government accounting continues to report the operations of Social Security within the "unified budget" context, this treatment of annual income and loss would clearly create a bias against investing the Social Security Trust Fund in equities. ${ }^{8}$

\section{IMPLICATIONS FOR SOCIAL SECURITY: GOVERNING THE INVESTMENT PROCESS}

The primary concern of Congress when it enacted the 2001 reform was the NRRIT and its ability to manage the investment of government assets efficiently and without political influence. This, not accounting, was the primary substantive issue motivating Republican resistance to the industry initiative. The Republicans were convinced that political pressures would inevitably affect how government assets were invested in private securities, which would undermine financial efficiency and - far more serious - the American democratic political system.

As addressed in the second discussion essay, Congress did what it could to make the investment of Railroad Retirement assets as much as possible a non-governmental activity. The

\footnotetext{
${ }^{8}$ One Social Security accounting issue that the Railroad Retirement experience did not address is how to treat the return on equities in financial projections. Both the Social Security and Railroad Retirement actuaries, like other actuaries, use the expected return on equities in making such projections. Government budgetary officials, like many financial analysts, use the "risk-adjusted" return that "costs" the risk in equities as the difference between the expected return and the return on riskless government securities. After deducting this "cost," they use the much lower return on government securities in their financial projections. This is a very thorny and contentious issue, which the Railroad Retirement experience did nothing to resolve or clarify.
} 
NRRIT was explicitly created as a non-governmental entity, with no government employees or agencies involved in its operations. The Trust was composed by statute in the image of a private multi-employer pension trust - with the Trustees primarily selected by management and labor, and the one "independent" trustee selected by these industry representatives. The Trust was charged, like a private pension trust, to make investment decisions solely in the interest of the plan participants. And it was instructed to use industry "best practice" to develop and execute a formal investment plan.

Consistent with the intent of Congress, the NRRIT has managed the assets of the Railroad Retirement program like a private pension trust, entirely free of political influence. But despite the fears of the Republicans, and hopes of the Democrats, the NRRIT experience does not provide much of a precedent for Social Security and the investment of Social Security Trust Fund assets.

The primary impediment in using the NRRIT as a model for Social Security is the lack of national organizations that could legitimately select Trustees to oversee a Social Security Trust Fund removed from the government and operated as a non-government entity. The railroad industry is highly organized, with the Association of American Railroads and the National Railway Labor Conference representing the carriers and the Cooperating Railway Labor Organizations representing labor. These organizations have an extensive history negotiating the terms and conditions of railroad employment and managing joint labor-management health and welfare plans. These organizations, implicitly recognized as representing rail management and labor by Section 2 of the Railway Labor Act and Section 105(3)(A)(ii) of the 2001 reform, selected the six management and labor NRRIT Trustees. If Railroad Retirement were a private multi-employer pension plan, these would be the organizations that would name the trustees of the plan's pension trust.

Many nations in Continental Europe have national management and labor organizations that function as "social partners" and negotiate and oversee national social security programs and other employment institutions. The status of these organizations is often defined in law and their negotiated decisions enforced by law. But there are no such organizations in the United States that could legitimately claim to represent all "employers" or "employees," and thus be in a position to oversee the investment of employer and employee contributions to the Social Security program. The U.S. Social Security system is purely a creation of the national government, with 
no formal "employer" or "employee" involvement. Unlike Railroad Retirement, there are no national organizations that could legitimately assume responsibility for managing the Social Security Trust Fund.

Congress could adopt various elements of the NRRIT design should it decide to invest the Social Security Trust Fund in equities and other private securities. These include 1) the mandate to invest solely in the interest of plan participants; 2) the NRRIT's extensive reporting requirements; and 3) authority given to an agency to sue the Trustees should that authority suspect malfeasance. Social Security, moreover, would no doubt include investment risk in actuarial projections. The triennial Actuarial Valuation of the Railroad Retirement program only addresses risk in projected employment and reports nothing about risk in investment returns. The Social Security program gets a far more extensive actuarial review from a much larger actuarial staff, with the results reported in its annual Trustees Report. That report addresses risk in program liabilities, such as risk in longevity projections, as well as risks in its employment projections, and could be expected to address risk in investment returns should the Trust Fund in equities.

Despite these "lessons," the NRRIT experience offers little guidance on the crucial questions of who the Trustees would be that would invest Social Security assets in equities how they would be chosen, their powers, and the procedural guidelines they must follow in making investment decisions. The NRRIT "solution" - to have Trustees who "represent" the primary interested parties, chosen by organizations that could legitimately name representative Trustees, with powers and procedures modeled on private pension trusts - is simply not relevant.

\section{IMPLICATIONS FOR SOCIAL SECURITY: DEALING WITH RISK}

The most important lessons for Social Security provided by the reformed Railroad Retirement program deal with the management of risk. Pension programs are extremely long-lived institutions and their finances will always move in unexpected ways. The 2001 Railroad Retirement reform introduced a mechanism - the tax adjustment "ratchet" - that automatically raised and lowered the payroll tax to offset changes in the program's finances. Such automatic stabilizers strengthen the financial viability of long-term pension programs. The inclusion of the ratchet was important in easing Congressional concerns about the investment of Railroad Retirement assets in equities and other risky securities. Some type of automatic adjustment 
mechanism, similar to the Railroad Retirement ratchet, thus seems critically important, financially and politically, to any viable program of investing the Social Security Trust Fund in equities.

The tax adjustment mechanism was a key element in the initial designs for reforming Railroad Retirement developed by the carriers in the 1980s and early 1990s. The carriers had developed proposals for privatizing Railroad Retirement and the "ratchet" was the device for reducing the payroll tax - then 21 percent of covered earnings - in the program's transition to a "normal" private employer plan. When the carriers presented their proposal to labor, the unions saw the benefit of investing Railroad Retirement assets in equities. But they saw no gain in giving up their statutory benefits, granted by an Act of Congress, and flatly rejected privatization. So the parties settled on a pay-as-you-go program, with Railroad Retirement assets invested as the assets in a private pension trust. In this new design, the tax adjustment ratchet became a device for keeping the program financially stable.

The ratchet enacted in the 2001 reform adjusted the Railroad Retirement payroll tax up or down based on the trailing ten-year average of the "account benefits ratio" - the ratio of Trust Fund assets to annual benefit outlays. The ratchet was designed to keep Trust Fund assets within a target band of 4 to 6 times annual benefits. As shown in Figure 3.1, the ratchet would automatically increase the payroll tax should the trailing ten-year average ratio fall below 4 times annual outlays; and cut taxes should the ratio rise above 6 times annual outlays. ${ }^{9}$ In both cases, tax rates would rise or fall by an increasing amount as the trailing ten-year average ratio strayed beyond the target band of four-to-six times annual outlays.

\footnotetext{
${ }^{9}$ Congressional Record (2001), Section 204; 26 USC Section 3241.
} 
Figure 3.1. The Tax Adjustment Ratchet, Railroad Retirement Payroll Tax Based on 10-Year Average Ratio of Assets to Annual Outlays

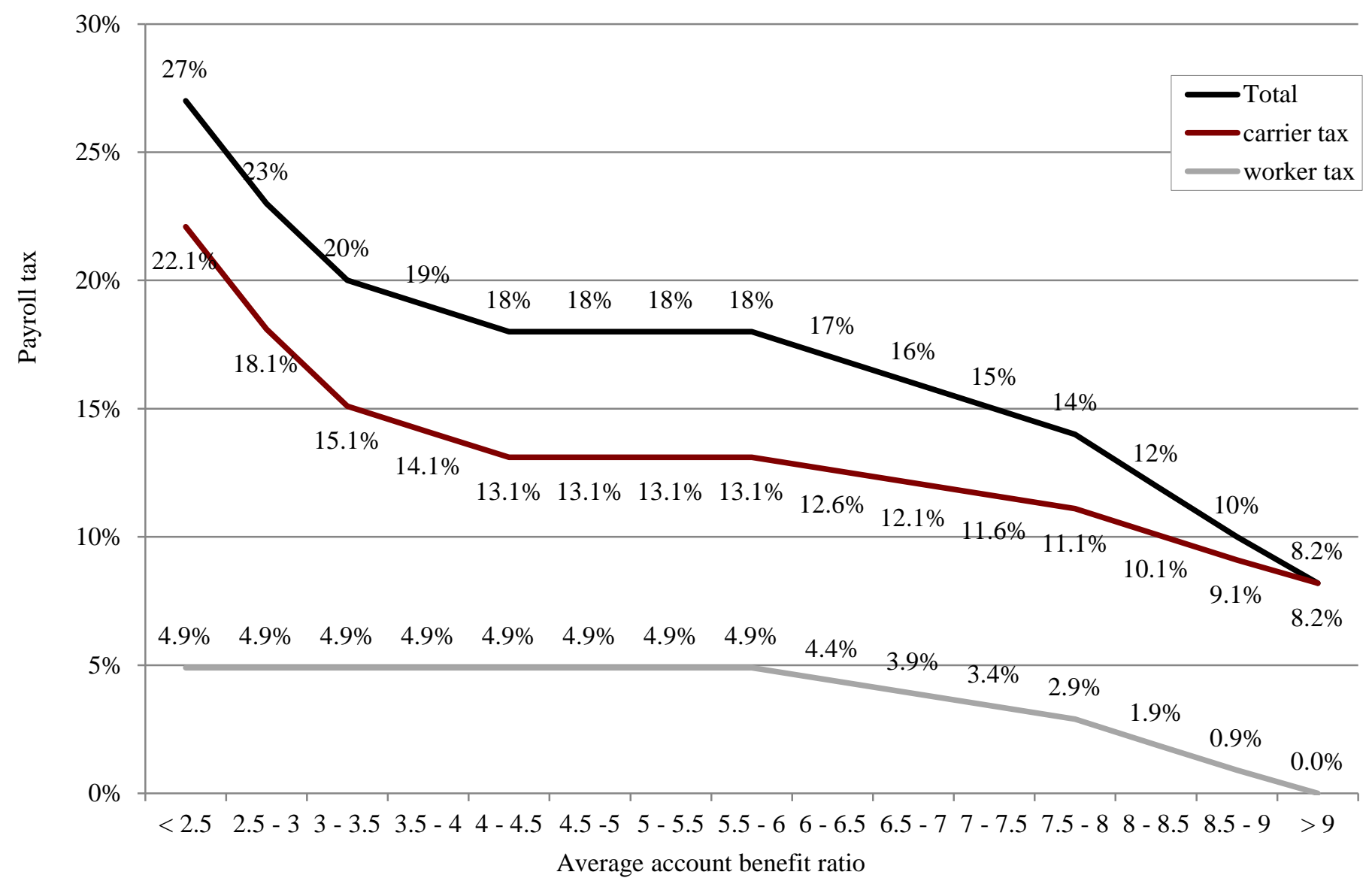

Source: Congressional Record (2001).

The ratchet was not designed to provide a complete solution to the problem of risk. The ratchet, a component of the reform package the industry negotiated and Congress enacted, could not push the payroll tax above 27 percent or below 8.2 percent of covered payroll. By basing the tax on the average ratio of Trust Fund assets to annual benefit outlays over the previous ten years, the design also dampened the tax response to sudden changes in the program's finances.

- The 8.2 percent floor on the payroll tax was an artifact of labor and management's agreement to split the "gains" of reform 50-50. So as the average account benefit ratio rose above 6 times annual outlays, the ratchet divided reductions in the payroll tax below 18 percent of covered payroll 50-50. The initial tax on workers was much lower than the initial tax on the carriers -4.9 vs. 13.1 percent of covered earnings. Once the average account benefit ratio exceeded 9 time annual outlays the ratchet eliminated the tax on workers. As any further 
reduction would only cut the tax on the carriers, violating the 50-50 understanding, there would be no further automatic reductions.

- The negotiators also agreed that carriers would bear the entire downside risk - that the carriers bear the full amount of any tax increase the ratchet imposed when the average account benefit ratio fell below 4 times annual outlays. The carriers, however, insisted on a cap - that the ratchet could not raise their tax above 22.1 percent of covered earnings. With the tax on workers capped at 4.9 percent, this limited the payroll tax funding the Railroad Retirement program to 27 percent of covered earnings.

- The railroad negotiators were eager to avoid large year-to-year swings in the payroll tax. So they had the ratchet set the payroll tax based on the relatively stable trailing ten-year average of the account benefit ratio. The Railroad Retirement Actuary, concerned that tax response to a downturn in the program's finances might be too slow, secured an increase in the tax rate increments. The top tax rate of 27 percent, agreed to by the carriers, is thus 50 percent higher than the baseline 18 percent rate; with the 22.1 percent top rate on the carriers nearly 70 percent higher than their baseline 13.1 percent rate. While taxes that high would dramatically improve the program's finances, the speed at which the ratchet can raise tax rates remains limited by its use of the trailing ten-year average ratio.

The Railroad Retirement ratchet can thus make very large adjustments to payroll tax rates, setting the rate anywhere from 8.2 to 27 percent of covered payroll. This extremely broad range is due to the expectation that the tax needed to maintain the account benefit ratio within the target band of four-to-six times outlays 1) would likely fall significantly over the course of the program's 75 year planning horizon; but 2) could also rise and fall quite dramatically over those 75 years. The ratchet nevertheless responded somewhat slowly to the very large financial shocks in 2008 and after.

Changes in Railroad Retirement finances that exceed the limits of the ratchet's automatic responses would require a political response. Should an 8.2 percent payroll tax produce an everrising account benefit ratio, Congress (and the industry) would need to decide how to redo the program. Congress (and the industry) would likewise need to decide what to do should a 27 percent payroll tax prove insufficient or should the ratchet respond too slowly to a sudden downturn in the program's finances. The critical measure of the ratchet's effectiveness in such 
cases is whether it gives the Congress (and the industry) enough time to fashion an adequate response.

The enactment of the 2001 Railroad Retirement reform suggests that Congress would require some type of automatic adjustment mechanism should it allow the Social Security Trust Fund to invest in equities. It also suggests that any such mechanism cannot be expected to provide a complete solution to the problem of risk. The design of the mechanism would specify the size and speed of the automatic adjustments, setting limits on its ability to stabilize Social Security's finances. A sufficiently large or long-lasting shock, which exceeds the mechanism's ability to respond, would require Congress to act. On the other hand, automatic adjustments large enough and fast enough to respond to such shocks could generate reactions so strong that Congress would also be required to act. The mechanism's design could only influence how and when Congress might intervene, not completely eliminate the need to intervene.

A Social Security program with a Trust Fund invested in equities should be far more stable and predictable than the current Railroad Retirement program. This is especially true for program's employment base, payroll tax revenues, number of beneficiaries, and annual benefit outlays. The ratio of Social Security beneficiaries to workers will rapidly rise as the Baby Boom generation ages, but then remain relatively stable. Nor will the Social Security Trust Fund likely be invested nearly as extensively in equities as the NRRIT. A Social Security program that invests in equities thus should not experience short-term shocks anywhere near as large, relative to the size of the program, as those seen in Railroad Retirement. The adjustment mechanism could thus be designed to respond rather slowly. The American political process, on the other hand, has convincingly demonstrated its inability to manage Social Security's finances. Despite knowing for decades that Social Security had a serious long-term financing shortfall, the nation for decades has failed to act. ${ }^{10}$ This argues for allowing the automatic mechanism to make adjustments large enough to adequately address as many anticipated risks as possible - so Congress would only need to act should those adjustments generated substantial political resistance.

Several nations in recent years have introduced automatic adjustment mechanisms to make their social security programs more sustainable. The great majority, however, operate traditional pay-as-you-go programs with small Trust Funds designed to buffer short-term cash-flow

\footnotetext{
${ }^{10}$ For some reasons why, see Diamond (1994).
} 
shortfalls, and hold only government bonds. They generally pay relatively high benefits, have relatively high tax rates, and anticipate revenue shortfalls in response to upcoming demographic shifts. Unlike the Railroad Retirement ratchet, nearly all of these automatic mechanisms only adjust benefits, not taxes - and are expected to adjust benefits downward. ${ }^{11}$

Canada, however, does have a social security program with a large Trust Fund, which is invested much like the NRRIT, and an automatic adjustment mechanism to keep the program's finances on-track. The Canada Pension Plan (CPP) - the earnings-related component of the nation's social security program - is funded by a 9.9 percent tax on covered earnings, pays a benefit of 25 percent of average indexed earnings, and is projected to have a Trust Fund equal to 6.5 times annual outlays, providing 15 percent of annual benefit payments, by 2080 . The CPP also has an automatic adjustment mechanism. The mechanism is not based on the ratio of assets to outlays, as in Railroad Retirement, but on projections by the Chief Actuary of Canada, conducted every three years, on the tax needed to sustain the program. If the projection indicates the 9.9 percent tax is too low, the politicians are given the opportunity to bring the program back into balance. If they don't, two things happen automatically: 1) retiree cost-of-living adjustments are eliminated until the next triennial review; and 2) taxes are raised, up to 0.2 percent of covered earnings per year, up to half the difference between the current tax and the minimum tax needed to restore sustainability in 75 years. Should the next triennial review again report a shortfall, the process is repeated. ${ }^{12}$

In one key respect the CPP mechanism is more suited to Social Security's needs than the Railroad Retirement ratchet. The CPP makes adjustments based on a long-term, forward-looking assessment of the program's finances; Railroad Retirement makes adjustments based on much shorter-term retrospective performance. As the finances of Social Security and the CPP are far more stable and predictable than those of the Railroad Retirement program, it is both feasible and preferable to adjust Social Security taxes and benefits based on long-term projections. ${ }^{13}$ It might also be advisable to include a trigger based on a shorter-term assessment, given the experience of the sharp financial shocks since 2008, to respond to risks of near-term cash-flow shortfalls that

\footnotetext{
${ }^{11}$ For a review see OECD (2012).

${ }^{12}$ The discussion of the Canada Pension Plan follows Monk and Sass (2009). Sweden also invests social security trust fund assets in equities and investment performance is incorporated in program's automatic adjustment mechanism when setting benefits. Palacios (2002).

${ }^{13}$ This assumes that there is no Constitutional issue in changing tax rates based on actuarial projections provided by the executive branch of government, rather than an act of Congress.
} 
the 75-year projection might not flag. But adjustments based on long-term projections would seem to be the norm, and any based on shorter-term assessments a safety measure.

The adjustments automatically made by the CPP, on the other hand, are decidedly not appropriate for Social Security. The burden of the CPP's tax and benefit adjustments by design falls most heavily on retirees. The three-year suspension of cost-of-living adjustments cuts the purchasing power of benefits 6 percent if inflation is running 2 percent a year, and 9 percent if inflation is running 3 percent a year. And these cuts are permanent - should cost-of-living adjustments resume, they resume from these post-freeze levels. The tax increases, by contrast, are unlikely to be anywhere near as large. And they could be reversed should conditions improve. Canada adopted these adjustments not because it viewed them as equitable, but as a political instrument: the threat of a benefit freeze is expected to mobilize retirees to "put a cannon" at the head of the politicians to get them to restore sustainability some other way. Given the U.S. track record in managing Social Security's finances, it seems advisable to adopt adjustments expected to be put in place, not to pressure politicians to act. ${ }^{14}$

That the Railroad Retirement ratchet automatically adjusts only taxes, while the CPP and in nearly all social security programs with automatic mechanisms adjust only benefits, is not especially significant for Social Security. The Railroad Retirement program is modeled on a standard employer defined benefit pension plan, where benefits are defined and the employer, typically, is responsible to pay what's needed. The CPP, as we have seen, placed the primary burden on benefits as a political device. The nations that introduced automatic adjustments to lower benefits generally had programs paying benefits that replaced a much higher share of preretirement earnings than the U.S. Social Security program. So what to adjust, and how much to adjust, remain open questions.

One lesson Railroad Retirement offers, however, is how to respond to surpluses. The primary concern when reviewing automatic adjustment mechanisms is how they handle shortfalls - do they raise taxes, cut benefits, delay eligibility, make some other adjustment. But how do they handle surpluses? The Railroad Retirement ratchet lowers taxes. One could assume

\footnotetext{
${ }^{14}$ As Monk and Sass write: "Concentrating the burden on current retirees is clearly at odds with general notions of social insurance objectives. The distribution of losses is also quite unfair: workers who will retire soon will pay the modestly higher contributions and then retire on unreduced benefits; workers just a few years older will have their CPP benefits substantially reduced. A small reduction in all benefits paid out over the next 76 years, a reduction akin to the increase in contributions, would be far more consistent with social insurance objectives." Monk and Sass (2009).
} 
that rail workers would spend that tax reduction on current consumption. For the carriers, the reduction would increase earnings, which would be used either to increase dividends or be retained and invested. To the extent that tax reductions on the carriers are retained and invested, the tax reduction increased the carriers' financial strength. Should the Railroad Retirement program subsequently face a financial shortfall, the carriers would be in a better position to pay the higher taxes the ratchet would introduce. Something similar could be done in Social Security - say by directing tax reductions on workers into individual accounts, which could be accessed only 1) to pay future payroll taxes, should taxes subsequently need to rise above the statutory rate; or 2) should the worker retire, become disabled, or die, or the value of the account exceed some specified amount. ${ }^{15}$

Finally, it is important to note that an automatic adjustment mechanism presupposes a program in balance, or moving toward balance. If Congress would require an automatic adjustment mechanism for the Social Security Trust Fund to invest in equities, the investment of Trust Fund assets in equities would need to be part of a package that produced a sustainable Social Security program. This would necessarily mean some combination of higher taxes, lower benefits, or delayed eligibility that would reduce the gap between tax revenues and benefit outlays, which income from the Trust Fund would need to fill, well below the currently projected shortfall of 25 to 30 percent scheduled benefits. A critical benefit of any reform package that included the investment of Trust Fund assets in equities would thus be the automatic adjustment mechanism. Though included in response to political demands for a mechanism to deal with risky equities, it would adjust the Social Security program in response to any shock, not just financial shocks. Had such a mechanism been in place, it could have introduced adjustments to Social Security, without the need for Congress to act, in response to the demographic shocks that have made current program unsustainable.

\footnotetext{
${ }^{15}$ Congress might also allow workers to access this account should they have a 'hardship' or need the funds for a "socially approved" use, such as paying for college or buying a house. A similar treatment could be used for employer contributions, though this could raise thorny legal issues, and passing the reduction to the employer is exactly analogous as the treatment used in Railroad Retirement.
} 


\section{References}

Clinton, President William. 1999. State of the Union Address. Washington, DC: 106th U.S. Congress.

Congressional Budget Office. 2001. Cost Estimate for H.R. 1140, Railroad Retirement and Survivors' Improvement Act of 2001. Washington, DC.

.2003. Evaluating and Accounting for Federal Investment in Corporate Stocks and Other Private Securities. Washington, DC. Available at:

https://www.cbo.gov/sites/default/files/cbofiles/ftpdocs/40xx/doc4023/01-08-03-stocks.pdf

Congressional Record. 2001. Railroad Retirement and Survivors' Improvement Act of 2001. Public Law 107-90. Congressional Record 147. Authenticated U.S. Government Information.

Diamond, Peter. 1994. "Insulation of Pensions from Political Risk." Working Paper 4895. Cambridge, MA: National Bureau of Economic Research.

Greenspan, Alan. 2001. Outlook for the Federal Budget and Implications for Fiscal Policy. Testimony before the Committee on the Budget, U.S. Senate. Washington, DC: The Board of Governors of the Federal Reserve System.

Monk, Ashby and Steven A. Sass. 2009. "Risk Pooling and the Market Crash: Lessons From Canada's Pension Plan." Issue in Brief 9-11. Chestnut Hill, MA: Center for Retirement Research.

Munnell, Alicia H. and Steven A. Sass. 2006. Social Security and the Stock Market. Kalamazoo, MI: W.E. Upjohn Institute for Employment Research.

Munnell, Alicia H., Geoffrey Sanzenbacher, and Mauricio Soto. 2007. "Working Wives Reduce Social Security Replacement Rates.” Issue in Brief 7-15. Chestnut Hill, MA: Center for Retirement Research.

Palacios, Robert. 2002. "Managing Public Pension Reserves, Part II: Lessons from Five Recent OECD Initiatives.” Social Protection Discussion Papers 33407. Washington, DC: The World Bank.

The Organisation for Economic Co-operation and Development (OECD). 2012. "Putting Pensions on Auto-pilot: Automatic-adjustment Mechanisms and Financial Sustainability of Retirement-income Systems.” OECD Pensions Outlook. Paris, France.

U.S. Office of Management and Budget. 2003. Budget of the United States Government, Fiscal Year 2003: Analytical Perspectives. Washington, DC.

U.S. Social Security Administration. 1997. Report of the 1994-1996 Advisory Council on Social Security. Washington, DC. 


\section{RECENT WORKING PAPERS FROM THE CENTER FOR RETIREMENT RESEARCH AT BOSTON COLLEGE}

An Assessment of the 2001 Reform of the Railroad Retirement Program

Steven A. Sass, June 2013

Reforming the Railroad Retirement System

Steven A. Sass, June 2013

How Do the Disabled Cope While Waiting for SSDI?

Norma B. Coe, Stephan Lindner, Kendrew Wong, and April Yanyuan Wu, June 2013

The Impact of Population Aging and Delayed Retirement on Workforce Productivity Gary Burtless, May 2013

Does Access to Health Insurance Influence Work Effort Among Disability Cash Benefit Recipients?

Norma B. Coe and Kalman Rupp, April 2013

How Will Older Workers Who Lose Their Jobs During the Great Recession Fare in the Long-Run?

Matthew S. Rutledge, Natalia Orlova, and Anthony Webb, March 2013

Can Long-Term Care Insurance Partnership Programs Increase Coverage and Reduce Medicaid Costs?

Wei Sun and Anthony Webb, March 2013

SSI for Disabled Immigrants: Why Do Ethnic Networks Matter?

Delia Furtado and Nikolaos Theodoropoulos, February 2013

The Use of VA Disability Benefits and Social Security Disability Insurance Among Veterans

Janet M. Wilmoth, Andrew S. London, and Colleen M. Heflin, February 2013

How Does the Composition of Disability Insurance Applicants Change Across Business Cycles?

Norma B. Coe and Matthew S. Rutledge, February 2013

The Economic Implications of the Department of Labor's 2010 Proposals for BrokerDealers

Alicia H. Munnell, Anthony Webb, and Francis M. Vitagliano, January 2013

All working papers are available on the Center for Retirement Research website

(http://crr.bc.edu) and can be requested bye-mail (crr@bc.edu) or phone (617-552-1762). 